\title{
IncRNA HAND2-ASI Regulates Prostate Cancer Cell Growth Through Targeting the miR-106a-5p/RBM24 Axis [Retraction]
}

\author{
Wei P, Yang J, Zhang D, Cui M, Li L. Onco Targets Ther. 2020;13:4523-4531.
}

At the authors request, the Editor and Publisher of OncoTargets and Therapy wish to retract the published article. Concerns were raised about the reliability of the cell apoptosis data presented in the article. In addition, the total number of cancer tissue samples reported in Figures 1A, 4E and 5D was inconsistent which risked statistical deviation occurring in the results. The authors reviewed the data from their study and determined that unintentional mistakes had been made and the findings of their study were now no longer valid. The authors wish to apologise for this and asked to retract the article.

Our decision-making was informed by our policy on publishing ethics and integrity and the COPE guidelines on retraction.

The retracted article will remain online to maintain the scholarly record, but it will be digitally watermarked on each page as "Retracted".

\section{Publish your work in this journal}

OncoTargets and Therapy is an international, peer-reviewed, open access journal focusing on the pathological basis of all cancers, potential targets for therapy and treatment protocols employed to improve the management of cancer patients. The journal also focuses on the impact of management programs and new therapeutic agents and protocols on patient perspectives such as quality of life, adherence and satisfaction. The manuscript management system is completely online and includes a very quick and fair peer-review system, which is all easy to use. Visit http://www.dovepress.com/testimonials.php to read real quotes from published authors. 